\title{
Corporate Governance and Performance (A Case Study for Pakistani Communication Sector)
}

\author{
Qaiser Rafique Yasser
}

\begin{abstract}
This study examines the relationship between Corporate Governance and corporate performance in communication sector of Pakistan. A set of listed companies has been investigated to analyze the relationship for the year 2009 . At the end conclusion shows that Better-governed firms are relatively more profitable, more valuable, and pay out comparative extra dividend to their shareholders and most importantly ensure sustainability. In line with Gimpers, Ishii \& Metrick (2003) and Brown \& Caylor (2004) and international best practices in corporate governance, a Corporate Governance Scoring Index (CGSI) has been created to measure the level of corporate governance practices being followed by the listed companies in Pakistan.
\end{abstract}

\section{Index Terms-Corporate Governance; Corporate Performance; Pakistan}

\section{INTRODUCTION}

The word "Governance" comes from the Greek word kybernan, meaning to "Steer", "guide" or "Govern". At its broadest, governance the act of governing refers to the relationship between the governors and the governed, such as that between the government and the people in a democracy, and has at its basis the decision-making powers abandoned by individuals to those in authority so that the common interests of country can be served. Defiantly the ship of state needs a competent captain and team to guide it but it also has to have a clear vision of where it is, where it is going, and how well it is progressing. So Governance mechanisms are designed for these ends.

The term "corporate governance" is susceptible of both narrow and broad definitions. Narrowly defined, it concerns the relationships between corporate managers, directors and shareholders. It can also encompass the relationship of the corporation to stakeholders and society. More broadly defined still, "corporate governance" can encompass the combination of laws, regulations, listing rules and voluntary private sector practices that enable the corporation to attract capital, perform efficiently, generate profit, and meet both legal obligations and general societal expectations.

OECD defines Corporate Governance, "A set of relationships, between a company's management, its board, its shareholders and other stakeholders. Corporate governance also provides the structure through which the objectives of the company are set, and the means of attaining those objectives and monitoring performance are determined.

Manuscript received April 26, 2011; revised May 27, 2011.

Qaiser Rafique Yasser is with Faculty of Economics and Business (FEB), University of Malaysia Sarawak (UNIMAS), Malaysia (email: qaiser_rafique1@hotmail.com).
Good corporate governance should provide proper incentives for the board and management to pursue objectives that are in the interests of the company and shareholders and should facilitate effective monitoring, thereby encouraging firms to use resources more efficiently.

"It is a system by which companies are directed and controlled". Cadbury Committee

La Porta, et al. (2000) Defined, "Corporate governance is, to a certain extent, a set of mechanisms through which outside investors protect themselves against expropriation by the insiders."

Corporate Governance developed as a way of ensuring that Owners of funds receive a return on their investment by protecting against management expropriation or use of the investment capital to finance pitiable projects. Specifically, corporate governance deals with the ways in which suppliers of equity finance to corporations assure themselves of getting a return on their investment in a ethical and bare way (Shleifer and Vishy 1997: 737). On the other hand, Hart (1995) suggests, necessitates the need for corporate governance for the inability to create perfect contracts. Corporate Governance issues arise wherever contracts are incomplete / immature and agency problems exist.

Diverse origins of capitalism formulate different approaches to financing corporations in different regions of the world according to their regional need and culture. The fruition of the corporate form can be traced from the family and closely held capitalism of the early 19 th century with the protection of ownership rights; through to the managerial capitalism of the early 20th century with further protection for listed corporations and limited liability; and finally the popular capitalism of the late 20th century with protection of minority interests and swarm ownership (Frentrop 2004; Clarke 2004, 2005).

According to OECD "Corporate governance is only part of the larger economic context in which firms operate that includes, for example, macroeconomic policies and the degree of competition in product and factor markets. The corporate governance framework also depends on the legal, regulatory, and institutional environment. In addition, factors such as business ethics and corporate awareness of the environmental and societal interests of the communities in which a company operates can also have an impact on its reputation and its long-term success.

While a variety of factors affect the governance and decision making processes of firms, and are important to their long-term success, the Principles focus on governance problems that result from the separation of ownership and control. However, this is not simply an issue of the relationship between shareholders and management, although that is indeed the central element. In some 
jurisdictions, governance issues also arise from the power of certain controlling shareholders over minority shareholders. In other countries, employees have important legal rights irrespective of their ownership rights. The Principles therefore have to be complementary to a broader approach to the operation of checks and balances. Some of the other issues relevant to a company's decision making processes, such as environmental, anti-corruption or ethical concerns." The code of corporate governance was initially introduced by Securities and Exchange Commission of Pakistan in early 2002 is the major step in corporate governance reforms in Pakistan. The major areas of enforcement include reforms of board of directors in order to make it accountable to all shareholders and better disclosure including improved internal and external audits for listed companies.

\section{LITERATURE REVIEW}

There are many studies emphasis the relationship between corporate governance and firm performance and its effect. One study shows that corporate governance has contributed to the company in enhancing operating performance and preventing fraud (Yeh, Lee, and Ko, 2002). It is important to note that the issue has also been evidenced that the performance of a firm is directly related to good corporate governance. Corporations with better corporate governance have better operating performance than those companies with poor corporate governance (Black, Jang, and Kan, 2002) which was concurrent with the view that better governed firms might have more efficient operations, resulting in higher expected returns (Jensen and Meckling, 1976). It is also believed that good corporate governance helps to generate investor goodwill and confidence. Another study had demonstrated that the likelihood of bankruptcy is related to poor corporate governance characteristics (Daily and Dalton, 1994).

"It is often alleged that boards of directors are more independent as the proportion of their outsider directors increases (John and Senbet 1998). However, Fosberg (1989) finds no relation between the proportion of Independent non Executive directors and various performance measures (i.e., SG\&A expenses, sales, number of employees, and return on equity).

Baysinger and Butler (1985) and Rosenstein and Wyatt (1990) show that the market rewards firms for appointing outside directors. Studies using financial statement data and Tobin's Q find no link between board independence and firm performance, while those using stock returns data or bond yield data find a positive link. The relation between the proportion of outside directors, a proxy for board independence, and firm performance is mixed.

Limiting board size is believed to improve firm performance because the benefits by larger boards of increased monitoring are outweighed by the poorer communication and decision-making of larger groups Lipton and Lorsch (1992); Jensen (1993). Consistent with this notion, Yermack (1996) documents an inverse relation between board size and profitability, asset utilization, and

\section{Tobin's Q.}

Klein (2002) documents a negative relation between earnings management and audit committee independence, and Anderson et al. (2004) find that entirely independent audit committees have lower debt financing costs. Frankel, Johnson and Nelson (2002) show a negative relation between earnings management and auditor independence (based on audit versus non-audit fees), but Ashbaugh, Lafond and Mayhew (2003) and Larcker and Richardson (2004) dispute their evidence. Kinney, Palmrose and Scholz (2004) find no relation between earnings restatements and fees paid for financial information systems design and implementation or internal audit services, and Agrawal and Chadha (2005) find no relation between either audit committee independence or the extent auditors provide non-audit services with the probability a firm restates its earnings.

In order to ascertain which hypothesis should be tested in the Pakistani environment, a number of research papers were studied in detail to arrive at a hypothesis which could be tested on local companies. The ensuing pages have briefs of some of those papers with hypothesis derived from those respective papers. Subsequently the hypothesis which will be tested in the project has been specified. Gompers, Ishii and Metrick (2003) in their study of corporate governance and equity prices, created a 'Governance-Index' to ascertain the level of shareholders' rights in an entity. For this index, 24 corporate governance rules divided into the following categories were used: Delaying hostile bidders, Voting rights, Director/Officer protection, Takeover defenses, and State Laws.

For computation of the index, one point was added for every provision that restricted shareholders rights. Accordingly, a firm having lower points had strong shareholders rights and categorized as the 'Democracy Portfolio' in the paper, while that with higher points had weak shareholder rights was categorized as the 'Dictatorship Portfolio'. The relationship of a firm's governance practices was tested with the following aspects which translate into equity prices: Firm value, Profits, Sales growth, Capital expenditure, and Corporate Acquisitions.

Brown and Caylor (2004) in their study on corporate governance and firm performance, the authors calculated a 'Gov-Score' comprising of 51 factors. These governance factors were spread over the 8 categories: Audit, Board of Directors, Charter/Bylaws, Director Education, Executive \& Director Compensation, Ownership, Progressive Practices, and State of Incorporation and calculated a Gov-Score for 2,327 firms and tested the association of these governance factors as against the performance of the firm. The performance measures used in this regard were: Return on Equity, Net Profit Margin, Sales Growth, Tobin's Q, Dividend Yield, and Share Repurchases. Their study concludes that good governance is related to good performance the vast majority of time.

Ghani and Ashraf (2005) examine corporate governance in Business groups operating in Pakistan. According to them, a number of empirical studies suggest that business groups, as an organizational form, are more prone to expropriation of minority shareholders. The authors have examined three broad research questions related to business groups and 
minority shareholders expropriation in Pakistan.

1) What are the key characteristics of business group firms that are different from those of non-business group firms?

2) Are firms affiliated with business groups more profitable than unaffiliated firms?

3) How does the stock market value group firms as compared to non-group firms?

For the second question, Return on Assets (ROA) was used as a measure while for the third question, the market valuation measure, Tobin's Q was used. The authors' have used a sample of all firms listed on the Karachi Stock Exchange (KSE) during 1998 through 2002 excluding firms from the banking, finance, real estate and insurance sectors. Group firms have higher liquidity and lower financial leverage than those of the non-group firms. Moreover, in the group firms, the five-year mean values of revenues and the five-year mean values of total assets grew faster than those of the non-group firms. Also Tobin's Q results show that the values are lower than those of the non-group firms. The paper concludes that external shareholders perceive firms affiliated with business groups to have relatively lower transparency and weaker corporate governance mechanisms than firms not affiliated with business groups. The market participants discount the value of group firms even though these firms are more profitable than non-group firms.

Bernard S. Black and Vikramaditya S. Khanna, studies how specific corporate governance reforms affect firm values. A central problem in studying how governance reforms affect firm values is that most reforms apply to all public companies in the country that adopts them. Thus, if share prices move when governance reforms are announced, the price changes may reflect the reforms, but could also reflect other new information.

\section{HYPOTHESIS}

H0: Strong Corporate governance practices result in strong corporate performance of the firm.

H1: Strong Corporate governance practices do not result in strong corporate performance of the firm.

By utilizing the similar research already conducted by Gompers, Ishii and Metrick in 2003 and Brown, Caylor in 2004 and Mubbashir in 2009, I conducted similar research on communication sector operating in the Pakistani environment.

\section{Methodology}

To test these hypotheses, a Corporate Governance Scoring Index (CGSI) has been created to measure the level disclosures of corporate governance practices being followed by the listed companies in Pakistan. This index has been created in such a manner that a CGSI score can be assigned to an entity based on the information which can be extracted from the annual reports of the institutions or from their corporate websites.
For the developments of the index, specifically with regards to the factors to be considered, assistance was taken from the Corporate Governance Survey carried out the JCR-VIS Credit Rating Company in March 2005. By increasing the factors taken in that survey trough review of international papers and other resources, a scoring mechanism better suited for the local environment was developed, which was used to assign a CGSI score to the sample entities taken for hypothesis testing. The CGSI constituted of the following areas:

4) Shareholders Rights (defined and protected)

5) Equity Structure

6) Board Composition

7) Transparency \& Disclosure

The CGSI comprised of 40 elements in total of which the four major areas constituted the bulk. Of these elements, 25\% pertained to shareholders rights, $25 \%$ Equity structure, another $25 \%$ to Board Composition and last $25 \%$ were to Transparency and Disclosure.

The correlation of CGSI with firm performance measures of the respective firms was computed to test the viability of the hypothesis.

The population was taken from Communication Sector of Pakistan, listed in Karachi Stock Exchange (KSE), that is the biggest and most liquid exchange and has been declared as the "Best Performing Stock Market of the World for the year 2002". As on December 31, 2007, 654 companies were listed with the market ca pitalization of Rs. 4,329,909.79 billion (US \$ 70.177) having listed capital of Rs. 671.269 billion (US $\$ 10.880$ billion).

The sample size to test the hypothesis was taken as one sector of KSE. The reason for choosing a single sector as against samples from various sectors was that entities operating in a single sector would in general face similar opportunities and threats. Accordingly, testing them against CGSI and its correlation with performance measures should apparently not give skewed results due to similarities in the working environment.

In the Pakistani economy some important sectors are financial, Sugar, energy, cement, fertilizer, telecommunication and textile sectors. As the Communication sector has a considerable number of listed entities, 11, this whole sector was chosen to test the hypothesis. However, the actual sample size was reduced due to non-availability of the financial statements and website of one entity concerns "Callmate Telips Telecom Limited". Accordingly the sample size was reduced to 10 entities.

The selected sample from the Technology and Communication companies listed on the KSE amounted to 10 companies. Communication sector is one the leading sector growing in Pakistan as well in south Asian region. The country is passing through some very turbulent times. The global recession has a major impact on Pakistan's economy. In addition to terrorism threats and power shortages have been other major challenges of time. Therefore economic growth has remained muted in the 2009 and these were hard times being faced by world economies. But at the same time we can observe the rapid growth of telecommunication sector in this first decade of $21^{\text {st }}$ century. Many foreign companies come to the Pakistan and invest in Communication sector and 
share their local experience in this region and no doubt to say earning good return.

We have taken financial data of sample companies and their corporate governance disclosures from their annual reports for 2009 that also available on the website of Karachi Stock Exchange. The annual reports used for extraction of data was the last completed financial year i.e. FY2009. These reports were used to extract data both for creation of CGSI and factors constituting firm performance. In addition certain data pertaining to share prices was extracted from the Karachi Stock Exchange website from historical data section.

"If good corporate governance is related to enhanced performance of an institution, such firms should perform better than institutions with poor corporate governance practices. Effective corporate governance increases the probability that managers invest in positive net present value projects, Shleifer and Vishny (1997), suggesting that better-governed firms have better operating performance, the first factor used in this analysis to measure firm performance.

Experts argue that the stock prices are related to governance practices. If their contentions are valid, a market premium should exist for relatively well-governed firms. Gompers et al. (2003), Bebchuk and Cohen (2004) and Bebchuk, Cohen and Ferrell (2004) show that firms with stronger stockholder rights have higher Tobin Q's (the same has been used in this analysis to measure valuation).

The free cash flow hypothesis Jensen (1986) maintains that firms' shareholders, where control lies mostly with managers, are less likely to receive free cash flow via cash dividend payouts. Larger free cash flow payouts reduce managers' abilities to invest in value-destroying projects, such as capital expenditures and acquisitions possessing negative net present values. Consistent with the notion that earnings are retained for empire building rather than for engaging in positive net value projects, Arnott and Asness (2003) find that firms with relatively smaller dividend payouts have relatively lower earnings growth, suggesting that better-governed firms pay out more cash to shareholders, the third measure for firm performance in this analysis.

The correlation of CGSI with firm performance measures of the respective firms was computed to test the viability of the hypothesis. The firm performance was measured using almost similar factors as used by Brown and Caylor in 2004, spread across three categories: operating performance, valuation and shareholder payout.

Similar measures (return on equity, profit margin and sales growth) have also been used by Gompers, Ishii and Metrick (2003). They had also used Tobin's Q to measure firm's valuation, as had previously been considered by others (e.g., Demsetz and Lehn (1985); Morck, Shleifer and Vishny 1988; Bebchuk and Cohen (2003); Bebchuk, Cohen and Ferrell (2004)). The measure of shareholder payout (dividend yield) has previously also been used by Fenn and Liang (2001) and Dittmar (2000).

The following performance measures are used in this analysis:

\section{A. Operating Performance}

$$
\text { Retum on Equity }=\frac{\text { Net Rrofit Generated During the Year }}{\text { Average Equity of the Firm at Year End }} \%
$$

$$
\begin{aligned}
& \text { Not Frofit Worgen }=\frac{\text { Net Profit Generated During the Year }}{\text { Tatal Revemase of the Fim at Year End }} \% \\
& \text { Sals Growth }=\frac{\text { Current Year's Total Rvemae }- \text { Last Year's Total Revenua }}{\text { Last Year'sTotal Revenue }} \%
\end{aligned}
$$

\section{B. Valuation}

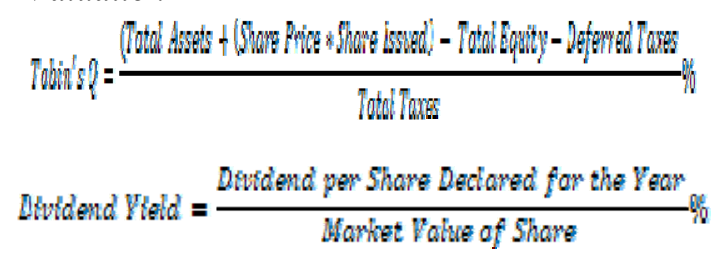

I performed three types of cross-sectional analyses, similar to Brown and Caylor (2004). I first correlate CGSI Score with each variable using Pearson correlation. To assess which categories and factors are associated with good or bad performance, I secondly correlate the four performance measures with the four governance categories using Pearson correlation and lastly all the 40 factors are correlated with the five performance measures using Pearson correlation."

\begin{tabular}{|c|c|c|c|c|c|c|}
\hline \multirow[b]{2}{*}{$\begin{array}{l}\mathrm{S} \\
\mathrm{r} \\
\dot{ } \\
\#\end{array}$} & \multirow[b]{2}{*}{$\begin{array}{l}\text { Comp } \\
\text { any }\end{array}$} & \multirow[b]{2}{*}{ SI } & \multicolumn{4}{|c|}{ Score Gained from } \\
\hline & & & $\begin{array}{l}\text { Shar } \\
\text { ehol } \\
\text { der } \\
\text { Rig } \\
\text { hts }\end{array}$ & $\begin{array}{l}\text { Equity } \\
\text { Structu } \\
\text { re }\end{array}$ & $\begin{array}{c}\text { Board } \\
\text { Compositi } \\
\text { on }\end{array}$ & $\begin{array}{c}\text { Transpare } \\
\text { ncy \& } \\
\text { Disclosure }\end{array}$ \\
\hline 1. & $\begin{array}{l}\text { Eye } \\
\text { Televisio } \\
\text { n Net }\end{array}$ & 68.5 & 20.0 & 12.5 & 18.5 & 17.5 \\
\hline 2. & $\begin{array}{l}\text { Pak } \\
\text { Datacom } \\
\text { Limited } \\
\end{array}$ & 67.5 & 20.0 & 07.5 & 20.0 & 20.0 \\
\hline 3. & $\begin{array}{l}\text { World } \\
\text { Call } \\
\text { Telecom }\end{array}$ & 65.0 & 15.0 & 12.5 & 20.0 & 17.5 \\
\hline 4. & PTCL & 62.5 & 20.0 & 10.0 & 12.5 & 20.0 \\
\hline 5. & $\begin{array}{l}\text { Telecard } \\
\text { Limited }\end{array}$ & 61.5 & 15.0 & 10.0 & 16.5 & 20.0 \\
\hline 6. & $\begin{array}{l}\text { Wateen } \\
\text { Telecom } \\
\text { Ltd. }\end{array}$ & 59.5 & 15.0 & 10.0 & 17.0 & 17.5 \\
\hline 7. & $\begin{array}{l}\text { Southern } \\
\text { Network }\end{array}$ & 52.5 & 17.5 & 02.5 & 15.0 & 17.5 \\
\hline 8. & $\begin{array}{l}\text { TRG } \\
\text { Pakistan }\end{array}$ & 52.5 & 17.5 & 05.0 & 12.5 & 17.5 \\
\hline 9. & $\begin{array}{l}\text { Netsol } \\
\text { Technolo } \\
\text { gies }\end{array}$ & 51.5 & 15.0 & 05.0 & 16.5 & 15.0 \\
\hline $\begin{array}{l}1 \\
0 .\end{array}$ & $\begin{array}{l}\text { Media } \\
\text { Times } \\
\text { Limited }\end{array}$ & 49.0 & 15.0 & 07.5 & 09.0 & 17.5 \\
\hline
\end{tabular}

\section{DATA ANALYSIS \& EMPIRICAL FINDINGS}

TABLE 1: CGSI SCORE OF COMPANIES IN DESCENDING ORDER.

The data collected from the 10 sample companies with respect to the factors of CGSI and the performance indicators.

The CGSI score index which had 40 elements could result in a maximum score of 100 . However, in terms of the actual score achieved, the overall results were not too good with a 
minimum score of only 49 and a maximum of 68.5 , which results in a mean value of 59 (that in percentage terms is only a score of 59\%) and a standard deviation of 7.13.

The total CGI score of each company in descending order is displayed in the table below: There are only three companies which scored more than $65 \%$ being Eye Television Net, Pak Datacom Limited and World Call Telecom. However, only one company scored less than $50 \%$ i.e. Media Times Limited scoring 49. This shows that majority of companies scored between 50-65; clearly depicting that on an average the corporate governance disclosures by listed companies are not of high quality. The areas scored through the CGSI were:

- Shareholders Rights

- Equity Structure

- Board Composition

- Transparency \& Disclosure

In first section there was 10 specific elements regarding Shareholders rights and their implementation and each element was allotted 2.5 score.

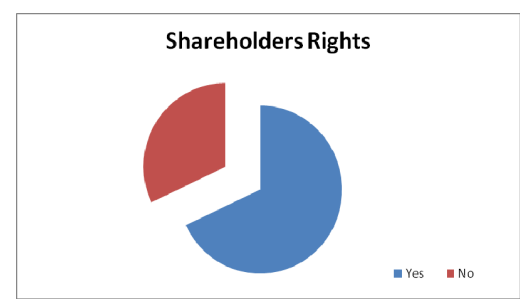

Figure 1: Share Holders Rights - Defined and Protected

In Pakistan basic shareholders rights are protected by regulatory authority. The following basic shareholders rights and strongly observed in Pakistan.

1) Secure method of ownership registration

2) Convey or Transfer of shares

3) Obtain relevant and material company information on a timely and regular basis

4) Participate and vote in general shareholder meetings

5) Elect and remove board members

Share in profits of the corporation

Registration is secured and in the process of being dematerialized through the CDC. Shareholders can demand a variety of information from company directly and have a clear right to participate in the annual general meeting of shareholders (AGM). Directors are elected by shareholders voting and can be removed through shareholders' resolution anytime. Change to company's basic documents like article of association, increasing authorized capital and sale of major corporate assets all require shareholder consent.

Some companies do not hold AGM or holds in a far off place and many companies do not participate shareholders in Companies profit. The decision about selection of company executives and fix their remuneration is in the hand of board but decision about selection of audit firm is in the hands of shareholders with the recommendation of audit committee.

Due to strong application of shareholders rights and their protection in Pakistan the scoring in first section i.e 'YES' score was only $68 \%$ that is second largest after transparency and disclosure.

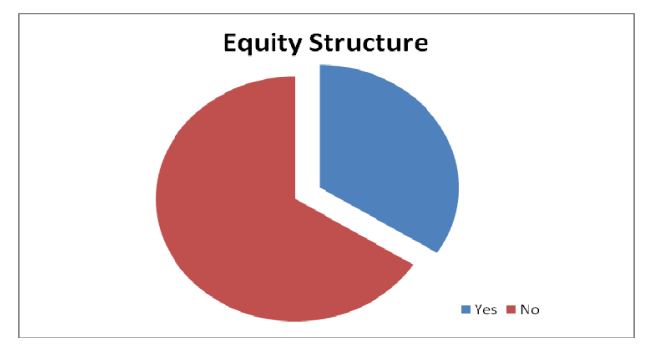

Figure 2: Equity Structure

The lowest scored area was related to the equity structure in public listed company that was $38 \%$. Ownership is concentrated in Pakistan; principal controlling shareholders are State, Families and foreign multinational companies. Families make extensive use of pyramiding to maintain control over their business groups. This ownership structure combined with high thresholds to initiate corporate actions, having limited effective protection of external investors and minority shareholders.

Historically the role of institutional investors has been limited, despite the fact that government owned investment funds were often represented on the boards of their portfolio companies but from last 5 years the role of institutional investor is mounting and has been observed an optimistic indication.

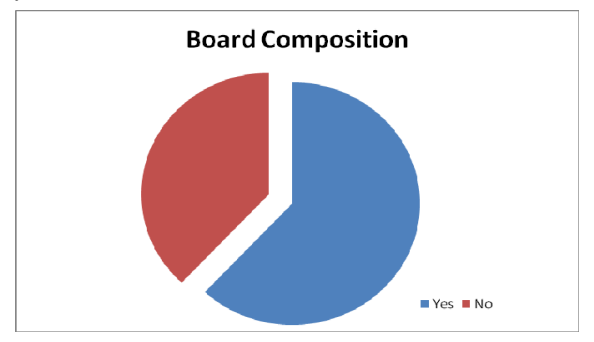

Figure 3: Board Composition

In business groups, broads are dominated by executive and non-executive members of the controlling families and by proxy directors appointed to act on their behalf. Inter-locking directorship is often used to retain majority control. Family dominated boards are less able to protect minority shareholders, and risk a loss of competitiveness as other boards become more professional.

Another appreciable step taken by around $80 \%$ of the companies was that the Chief Executive Officer (CEO) of the company was not a part of the Board's Audit Committee. Having the CEO as a member of the audit committee not only casts doubts on the functioning of the committee but it also impairs perceived independence of the internal auditors. The dual position of CEO and chairman of board is also common in many companies in Pakistan which create one many show in the company.

One of the objectives of the Code is to revitalize the role of boards in the governance of firms. The Code strengthens the role of non-executive directors, restricting the percentage of executive directors to 75 percent in non-financial firms and recommending that institutional investors be represented.

In this section, comprising of 10 specific elements, the consolidated average 'YES' score was $63 \%$. 
Transparency and Disclosure

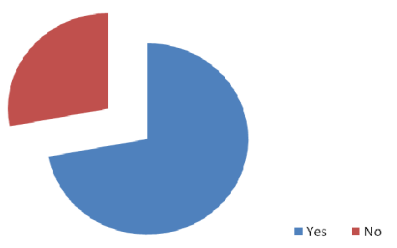

Figure 4: Transparency and Disclosure

Transparency and Disclosure section gained highest score and gained "72". It is generally agreed that the quality and timeliness of financial disclosure has improved over the past few years. This is in part attributed to the increasing monitoring role of the SECP and to the requirements of the new Code. Law and regulation require the disclosure of most non-financial items recommended by the OECD Principles. Stated Bank of Pakistan (SBP) mandates comprehensive disclosure for banks and Development Financial Institutions.

Shareholders owning 10 percent or more of voting capital must disclosure their ownership and the annual report includes the pattern of major shareholders. Pakistan follows IAS 24 and there is general agreement that actual disclosure of related party transactions leaves much to be desired. The SECP issued a specific guideline to have more information on related party transactions. The disclosure about remuneration of chief executive and other executives and the board is mandatory separately.

The data with regards to firm performance of the sample firms has had varied results. One (1) company in the sample having negative equity, due to accumulated loss in previous year their equity and reserve sections was showing negative results. Of the remaining 9 companies, 7 had made profits and their returns ranged between 1-33\% with five companies having returns on equity in double figures.

TABLE 2: RETURN ON EQUITY

\begin{tabular}{|c|c|c|}
\hline $\begin{array}{c}\text { C } \\
\text { GSI }\end{array}$ & Company Name & $\begin{array}{c}\text { ROE } \\
(\mathbf{\%})\end{array}$ \\
\hline $\begin{array}{c}68 \\
5\end{array}$ & Eye Television Net & 33 \\
\hline $\begin{array}{c}52 \\
.5\end{array}$ & TRG Pakistan & 31 \\
\hline $\begin{array}{c}67 \\
.5\end{array}$ & Pak Datacom Limited & 27 \\
\hline $\begin{array}{c}59 \\
5\end{array}$ & $\begin{array}{c}\text { Wateen } \\
\text { Limited }\end{array}$ & 22 \\
\hline 51 & Netsol Technologies & 12 \\
\hline 5
\end{tabular}

Seven (7) of the Ten (10) sample companies were in profit and the net profit margins of these 11 companies ranged between $1-30 \%$. Five of the sample companies managed to attain a net profit margin in double digits with TRG Pakistan and Netsol Technologies exceptions with margins of $30 \%$ and $27 \%$ respectively. Of the 3 companies in the red, 1 company has a slight negative margin and Southern Network negative margin being 33\%.

TABLE 3: NET PROFIT MARGIN.

\begin{tabular}{|c|c|c|}
\hline $\begin{array}{c}\text { C } \\
\text { GSI }\end{array}$ & Company Name & Net Profit Margin (\%) \\
\hline $\begin{array}{c}52 . \\
5\end{array}$ & TRG Pakistan & 30 \\
\hline $\begin{array}{c}51 . \\
5\end{array}$ & Netsol Technologies & 27 \\
\hline $\begin{array}{c}68 . \\
5\end{array}$ & Eye Television Net & 22 \\
\hline $\begin{array}{c}67 . \\
5\end{array}$ & Pak Datacom Limited & 16 \\
\hline $\begin{array}{c}62 . \\
5\end{array}$ & PTCL & 15 \\
\hline 59. & Wateen Telecom & 06 \\
\hline 5 & Limited & 01 \\
\hline 61. & Telecard Limited & $(.51)$ \\
\hline 5 & Media Times Limited & $(06)$ \\
\hline $\begin{array}{c}69 \\
6\end{array}$ & World Call Telecom & $(33)$ \\
\hline 52. & Southern Network & \\
\hline 5 & & \\
\hline
\end{tabular}

\begin{tabular}{|c|c|c|}
\hline \multicolumn{3}{|c|}{ TABLE 4: SALES GROWTH } \\
\begin{tabular}{c} 
CSI \\
\hline $\begin{array}{c}65 \\
0\end{array}$
\end{tabular} & Company Name & $\begin{array}{c}\text { Sales } \\
\text { Growth }\end{array}$ \\
\hline $\begin{array}{c}61 \\
5\end{array}$ & Telecard Limited & $172 \%$ \\
\hline $\begin{array}{c}59 \\
.5\end{array}$ & $\begin{array}{c}\text { Wateen Telecom } \\
\text { Limited }\end{array}$ & $99 \%$ \\
\hline $\begin{array}{c}52 \\
5\end{array}$ & TRG Pakistan & $85 \%$ \\
\hline 51 & Netsol Technologies & $73 \%$ \\
\hline 5
\end{tabular}

\begin{tabular}{|c|c|c|}
\hline \multicolumn{3}{|c|}{ TABLE 5: ToBIN's Q } \\
$\begin{array}{c}\text { C } \\
\text { GSI }\end{array}$ & Company Name & $\begin{array}{l}\text { Tobin' } \\
\text { s Q }\end{array}$ \\
\hline $\begin{array}{c}62 \\
5\end{array}$ & PTCL & 7757 \\
\hline $\begin{array}{c}65 \\
.0\end{array}$ & World Call Telecom & 4956 \\
\hline $\begin{array}{c}68 \\
5\end{array}$ & Eye Television Net & 4811 \\
\hline $\begin{array}{c}52 \\
5\end{array}$ & TRG Pakistan & 3333 \\
\hline $\begin{array}{c}52 \\
5\end{array}$ & Southern Network & 3282 \\
\hline $\begin{array}{c}61 \\
5\end{array}$ & Telecard Limited & 2799 \\
\hline $\begin{array}{c}59 \\
5\end{array}$ & Wateen Telecom & 2577 \\
\hline $\begin{array}{c}49 \\
.0\end{array}$ & Media Times Limited & 1255 \\
\hline $\begin{array}{c}51 \\
5\end{array}$ & Netsol Technologies & 824 \\
\hline 67 & Pak Datacom Limited & 599 \\
\hline 5
\end{tabular}


In the long run frame, a company can show good performance if it has a steady sales growth as this helps it in enhancing its market positioning amongst other factors. As FY2009 was not a good year for the economy, but communication sector prove improvement in sales margin from previous year. Only one company "Pakistan Telecommunication" observed declining in sale from last year, due to internal management problems with employees union and infamous news of denationalization.

The Tobin's Q ratio compares the market value of a company against the company's assets. A higher ratio indicates that the market value of the company is greater than that of its assets while a ratio of less than one indicates that the market value is less than the value of the company's assets. In the sample 10 companies, all had a positive ratio.

TABLE 6: Dividend Yield

\begin{tabular}{|c|l|c|}
\hline CGSI & \multicolumn{1}{|c|}{ Company Name } & $\begin{array}{c}\text { Dividend } \\
\text { Yield }\end{array}$ \\
\hline 68.5 & Eye Television Net & $184 \%$ \\
\hline 67.5 & Pak Datacom Limited & $101 \%$ \\
\hline 62.5 & PTCL & $87 \%$ \\
\hline 52.5 & TRG Pakistan & $1 \%$ \\
\hline 65.0 & World Call Telecom & $0 \%$ \\
\hline 61.5 & Telecard Limited & $0 \%$ \\
\hline 59.5 & Wateen Telecom Limited & $0 \%$ \\
\hline 52.5 & Southern Network & $0 \%$ \\
\hline 51.5 & Netsol Technologies & $0 \%$ \\
\hline 49.0 & Media Times Limited & $0 \%$ \\
\hline
\end{tabular}

The dividend yield ratio compares the latest dividend received with the current market value of the share as an indicator of the return being earned on the shares. With FY2009 being a year with negative sales growth in many sectors in general, the profitability position also suffered. Out of the 10 sample companies, Nine (9) companies managed to improve upon their previous year's sales and accordingly 7 companies made profits with 3 making losses. This negative impact on the profitability leads to low dividend declaration in the communication sector during FY2009, with only 4 companies announcing a dividend. Dividend ranged between Rs. 0.10 per share to Rs. 70 per share with Pak Datacom Limited declaring the highest dividend.

I performed various cross-sectional analyses, similar to Brown and Caylor (2004). I first correlated CGSI Score with each variable using Pearson correlations. The three variables under operating performance i.e. return on Equity, Net Profit Margin and Sales Growth has a positive association with CGSI score. The strongest association amongst all factors is that of Return on Equity growth with companies having a higher score 33.

In valuation, Tobin's $Q$, has very small association with the CGSI score. This confirms the common perception prevalent in the country that good governance practices are not adding much to the value of a firm and listed concerns are only following the corporate governance regulations to conform with regulations and not for the betterment of the company in particular and the business segment in general.

Under shareholder payout, dividend Yield also has perfect association with the CGSI score. With FY2009, being a bad year for Pakistani economy, profitability levels are barely positive for a number of companies in the sector and accordingly, dividend payout was low resulting in a low dividend yield across the country.

To assess which categories are associated with good or bad performance, I correlate the five performance measures with the four governance categories using Pearson correlation. When the categories were consolidated into a CGSI score, Sales growth and Tobin Q had a weak positive association with it.

'Sales growth' has a weak positive association with three of the four main components of CGSI, with the last component, transparency and disclosure having little or no association. Subsequent to the top level correlation analysis, the same was done separately for each of the 40 CGSI factor against the 5 performance factors. First all the elements of 'Shareholders Rights' were tested against the five performance measures. Majority of the factors had little or no association with the performance measures. In Equity Structure portion the outliers on the positive side being single person holding greater than $50 \%$ shares, having the office of the Chairman and CEO separate and the Chairman gives a separate review to the shareholders in the annual report. Single person holding greater than $50 \%$ shares has shown a weak positive association with the measure of value of the company, Tobin's Q. Chairman and CEO being separate persons has shown a weak positive association with Net Profit Margin while presence 1 of a Chairman's Review in the annual report has a weak positive association with sales growth.

Weak negative association has been shown by holding of a minimum of 4 board meetings a year with both returns on equity and sales growth. While a similar weak negative association is between individual attendance level of directors in board meetings with sales growth and disclosure of board committees with return on equity.

Secondly, all the elements of 'Board Composition' were checked against the 5 performance factors. All factors barring one had little or no association. The different factor being the level of CEO's salary in contrast to the overall salary expenses of an entity had weak positive association with sales growth.

- 'Transparency and Disclosure' showed a very different picture in comparison to the previous two areas of the CGSI. Here the presence of a big external audit had a strong positive association with 'sales growth'. Having a good auditor also showed a weak positive association with Return on Equity and Net Profit Margins.

\section{CONCLUSION}

The aim of this paper is to analyze the link between the corporate governance quality and performance of Pakistani listed firms.

I analyze the performance effects of corporate governance quality with reference to both valuation and operating performance. I prepare a Corporate Governance Scoring Index to standardize a corporate governance index with the help of 40 indicators in for sectors of corporate governance (Shareholder Rights, Equity Structure, Board Composition and Transparency and Disclosure). I compare CGSI with Operating performance and valuation and finds positive results. 
The factor which was present in the annual reports of all the 10 companies was the presence of a Mission and Vision statement, Corporate Strategy Statement while those found completely lacking were: Profile of directors and length of their association with the company specially non executive directors, Board's governing principles, Scope of Board Committees, CEO's review in Annual report, Profiles of the Executive Management, and Executive Management Committees and their scope.

Return on Equity had a positive association with 7 of the 40 CGSI factors (i.e. 18\%). These seven were predominantly from 'Equity Structure and Transparency \& Disclosure'. These factors were: Quality of the external auditor and timely completion of audit, Absence of qualifications in the audit report, Stability of Revenue stream and Profitability History, Positive accumulated profits and reserves, Corporate Social Responsibility, and Timing of holding the AGM. Mainly, the CGSI factors had a little or no association with Return on Equity, while only 3 out of the 40 factors (i.e. $8 \%$ ) had a weak negative association with Return on Equity.

Net Profit Margin had a weak positive association with 6 of the 40 CGSI factors (i.e. 15\%). There was one exception, which had a weak negative association, while all others had little or no association with Net Profit Margin. These six factors with weak positive association were predominantly from 'Transparency and Disclosure' being: Separation of the offices of the Chairman or Board and CEO, CEO's absence from the audit committee as a member and chairman of Audit Committee must be a not executive director, Quality of the external auditor, Absence of qualifications or emphasis paragraph in the audit report, and Positive accumulated profits and reserves.

Sales Growth had a strong positive association with 12 of the 40 CGSI factors (i.e. $30 \%$ ) as well as a weak positive association with 2 of the 40 CGSI factors (i.e. $5 \%$ ).

The two factors having a weak positive association were quality of external auditor and corporate social responsibility. These twelve factors with strong positive association chiefly included: Stability of Revenue stream and Profitability History, Positive accumulated profits and reserves, Proportion of CEO's salary in contrast with total salary expenses, Timing of holding the AGM subsequent to year end, venue of AGM and AGM being held within normal business hours, Timely completion of audit, Absence of qualifications in the audit report, Chairman's Review, Presence of an Environment, Health and Safety Policy, and Quality Policy Tobin's Q had a weak positive association with 1 of the 40 CGSI factors (i.e. $2 \%$ ) i.e. a single person or an entity holding shares of the company in excess of $50 \%$. There was one exception, which had a weak negative association, i.e. CEO's presence as a member in the Board's Audit Committee, while all others had little or no association with Tobin's Q.

\section{REFERENCES}

[1] ASX Corporate Governance Council, Corporate Governance Principles and Recommendations, 2007.

[2] Bernard S. Black and Vikramaditya S. Khanna, Can corporate governance reforms increase firms' market value: Evidence from India, 2007, University of Texas Law School Law and Economics Research, Paper No. 86.

[3] Brown and Caylor, Corporate Governance and Firm Performance, 2004.

[4] Corporate Restructuring and Governance in East Asia (1999), Magdi Iskander, Gerald

[5] Frentrop, L. (2004) Corporate Governance 1602-2002, Amsterdam: Prometheus

[6] Goyer, M. (2001) 'Corporate Governance and the Innovation System in France,' Industry and Innovation, 8 (2): 135-58.

[7] McDonnell, B. (2002) 'Convergence in Corporate Governance: Possible But Not Desirable,' Villanova Law Review 341, 350-353.

[8] Shleifer, A., and R.W. Vishy (1997) 'A Survey of Corporate Governance', Journal of Finance 52.2: 737-83

[9] Meyerman, Dale F. Gray, and Sean Hagan by Finance and Development.

[10] Ghani and Ashraf (2005),Corporate Governance, Business Group Affiliation, and Firm Performance: Descriptive Evidence from Pakistan, 2005, LUMS CMER Working Paper Series, Working Paper No. 05-35, -.

[11] Gompers Ishii and Metrick (2003) Corporate Governance and Equity Prices, Quarterly Journal of Economics, 118(1), Pg. 107-155.

[12] Mubbashir (2009) Corporate Governance - International Best Practice, Global Journal of Finance and Management, 1(1), Pg. 1-20

[13] The Foundation for Corporate Governance Research for Pension Funds (SCGOP), Manual Corporate Governance, 2004.

[14] OECD, Principles of Corporate Governance, 2004, -, -, 11 Weil Gotshal \& Manges LLP, Comparative Study of Corporate Governance Codes Relevant to the European Union and its Member States, 2002, European Commission Internal Market Directorate General, -, 28.

[15] McKinsey on Finance (2007) McKinsey \& Company's Corporate Finance practice.

[16] Monks, Robert A.G. and Minow, Nell, Corporate Governance (Blackwell 2004)

[17] Sir Adrian Cadbury (2000). Family Firms and Their Governance, Creating tomorrow's Company from Today's: Egon Zehnder International.

Qaiser Rafique Yasser is a doctoral degree candidate in Faculty of Economics and Business (FEB), University of Malaysia Sarawak (UNIMAS), Malaysia. He earned his Master of Commerce (M.Com) from University of the Punjab, Pakistan. Mr. Qaiser Rafique has been working as financial and legal advisor for various public \& private firms as well Director of AMC Global. 